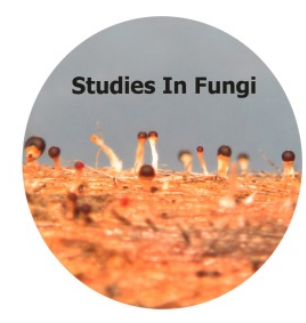

Studies in Fungi 4(1): 263-273 (2019) www.studiesinfungi.org ISSN 2465-4973

\title{
Article
}

Doi 10.5943/sif/4/1/28

\section{Occurrence of manglicolous lichens in Calabarzon, Philippines}

\section{Lucban $\mathrm{MC}^{1}$ and Paguirigan $\mathrm{JAG}^{2}$}

${ }^{1}$ The Graduate School, University of Santo Tomas, España, Manila, Philippines 1008
${ }^{2}$ Department of Biological Sciences, College of Science, University of Santo Tomas, España, Manila, Philippines 1008

Lucban MC, Paguirigan JAG 2019 - Occurrence of Manglicolous Lichens in Calabarzon, Philippines. Studies in Fungi 4(1), 263-273, Doi 10.5943/sif/4/1/28

\begin{abstract}
Various species of mangrove trees thrive in the mangrove forests of Calabarzon, Philippines including species of Avicennia marina, Rhizophora mucronata, and Rhizophora apiculata, which house various lichen species but very little available information on the diversity of these epiphytes is known. A survey of 90 decaying mangrove woods from 3 mangrove sites in Calabarzon including Laiya Batangas, Tanza Cavite and Pagbilao Quezon recorded a total of 40 lichen species classified under 25 genera and 14 families. Rhizophora apiculata (bakawang lalaki) was found the most preferred lichen establishment host as it housed 23 lichen species followed by Rhizophora mucronata (bakawang babae) with 17 lichen species and Avicenia marina with 7 lichen species. Lichens that belong to family Arthoniaceae, Caliciaceae, Parmeliaceae, Collemataceae, and Graphidaceae were the highest recorded. Most of these manglicolous lichens were classified as crustose (60\%) and foliose (40\%) lichens. Out of these manglicolous lichens identified, 29 species were found to be new records of lichens in the Philippines.
\end{abstract}

Key words - corticolous - epiphytes - estuarine - mangrove - new record

\section{Introduction}

As an archipelagic country made up of more than 7,000 islands, the Philippines have one of the longest coastlines in the world extending up to $36,289 \mathrm{~km}$. It is located at $13^{\circ} 00^{\prime} \mathrm{N}, 122^{\circ} 00^{\prime} \mathrm{E}$, along the tropical band where mangroves thrive. The country holds at least $50 \%$ (Primavera et al. 2004) of the world's approximately 65 mangrove species (Kathiresan \& Bingham 2001). Mangrove ecosystems are one of the world's most species diversified and productive ecological system .The mangroves habit is a complex of physiological adaptations enabling the survival and success of organism in estuarine ecosystem (Hogarth 2015).

Mangroves are the unique ecosystem developed along estuarine seacoasts and river mouths in tropical and subtropical regions of the world. They are commonly found in the intertidal zone and are considered bridges between terrestrial and marine ecosystems, harboring a unique microbial biodiversity. Mangrove forests are one of the world's most productive tropical ecosystems (Odum \& Heald 1972, Lugo \& Snedaker 1974, Smith et al. 1991, Kathiresan 2000, Logesh et al. 2012). Mangrove trees are fascinating study objects for the mycologist because the bases of their trunks and aerating roots are permanently or intermittently submerged. Whereas the upper parts of roots and trunks rarely or never reached by the salt water, although, they sometime may be subjected to saline spray (Logesh et al. 2012). Thus, terrestrial fungi and lichens occupy the upper part of the 
trees and marine species occupy the lower part. At the interface there is an overlap between marine and terrestrial fungi (Kohlmeyer 1969).

Lichens have been traditionally described as symbiotic organisms (holobionts) resulting from the close morpho-physiological interaction between a heterotroph (mycobiont) and at least one photosynthetic (photobiont) partner, which can be green microalga (phycobiont) and/or cyanobacteria (Logesh et al. 2012). They are found on every continent and are dominant organisms that inhabit around 8\% of the world's land surface (Margulis \& Barreno 2003). They are mostly found on soil, rocks and trees while some grow on old wood, dead branches, rails and rocks (Nash 2008). Due to their unique nature and physiology, lichens have an ability to colonize various substrates such as epiphytes (Margulis \& Barreno 2003). The different species of sporophytes provide excellent habitat for lichens vital role in colonization (Kohlmeyer 1969). Lichens present in the mangroves are termed manglicolous lichens (Raja et al. 2012). The population of lichens on mangroves is very low when compared to the lichens of terrestrial ecosystems, as their growth is arrested by high level of salinity and moisture (Logesh et al. 2012).

The Calabarzon region is located in the Southwestern part of the Island of Luzon and has a total land area of 16,560 square kilometers. It is the second most densely populated region in the country, principally because it is closest region to Metro Manila (Berja-Lusterio \& Colson 2008). It is compose by the provinces of Cavite, Laguna, Batangas, and Pagbilao Quezon. As of 2010, the total mangrove area of Cavite stands at 150.39 hectares with plantation areas of approximately 32.65 hectares. It provides an overview of the mangrove cover from 297.66 hectares in 2003 to 150.39 hectares in 2010. Batangas on the other hand has an estimated total mangrove area of 610.94 hectares. Around 517.27 hectares are old stands while 93.67 hectares have been planted during the last ten years and has twelve mangrove species and eight associate species. Mangrove species include Avicennia alba, Avicennia marina, Avicennia officinalis, Bruguiera gymnorrhiza, Bruguiera sexangula, Ceriops decandra, Ceriops tagal, Excoecaria agallocha, Rhizophora apiculata, Rhizophora mucronata, Rhizophora stylosa, and Sonneratia alba. Mangrove associate species include Acacia farnesiana, Dolichandrone spathacea, Hibiscus tiliaceus, Ipomoea pescaprae, Morinda citrifolia, Pongamia pinnata, Sesuvium portulacastrum, and Terminalia catappa (Samson \& Rollon 2011). Pagbilao Experimental Mangroves is 145 hectare as declared by Pagbilao Experimental Forest by virtue of Bureau of Forest Development (BFD) Administrative Order NO. 7 (s.1975). It has 28 mangrove species. In general, based on the Department of Environment and Natural Resource (DENR) data, Calabarzon is covered with 55 percent of forests, including mangroves.

In the Philippines, less research has been undertaken on the manglicolous lichens on specific mangrove community. In order to gain better understanding of these fungal species in mangroves, a study of the occurrence of manglicolous lichens in specific mangrove species was undertaken.

\section{Materials \& Methods}

\section{Study Site}

The study site is comprise of 3 different locations in Calabarzon including Laiya Batangas $13.675^{\circ} \mathrm{N}, 121.390^{\circ} \mathrm{E}$, Pagbilao Mangroves Experimental Forest $13^{\circ} 58.525 \mathrm{~N}, 121^{\circ} 43.523 \mathrm{E}$, and Tanza Cavite Mangrove Park $14.3520^{\circ} \mathrm{N}, 120.8384^{\circ} \mathrm{E}$ (Fig. 1).

\section{Collection and treatment of bark samples}

The decaying substrate of Rhizophora mucronata, Rhizophora apiculata, and Avicenia marina were collected from the three-mangrove forest of CALABARZON on June-April 2017. A total of 90 decaying wood substrates were collected from each mangrove species Avicenia marina, Rhizophora apiculata, and Rhizophora mucronata. The lichen specimens collected from the host mangrove species were properly labeled for further studies in the laboratory. Lichen samples were then classified into crustose, foliose \& fruticose lichen growth forms as per standard literature (Broad 1989, Muthukumar \& Tarar 2006, Rai et al. 2014). Lichen samples were identified based on 
their morpho-anatomical features with the aid of available taxonomic keys and various references e.g. Gruezo 1979, Goward et al. 1994, Malcolm et al. 2011, Santiago et al. 2013, McCarthy 2015.

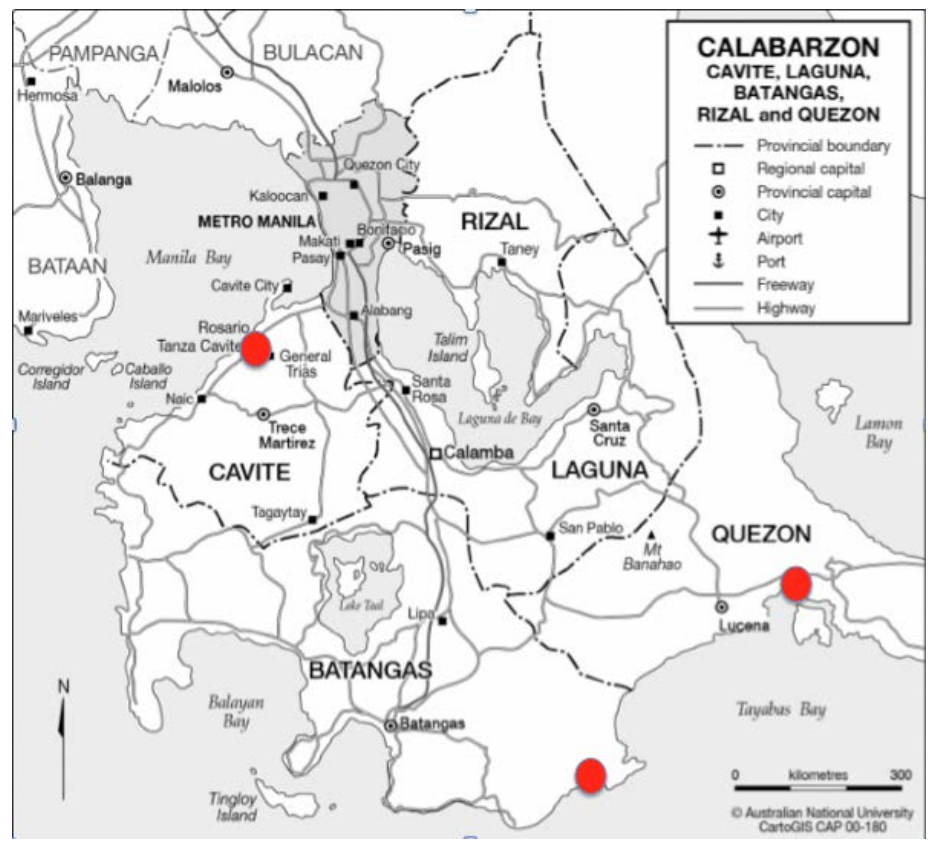

Fig. 1 - Lichen collection sites in Calabarzon, Philippines

\section{Results}

In this study, the species of manglicolous lichens from Calabarzon, Philippines were arranged alphabetically following genera and species whose valid nomenclature follows mycobank.org and indexfungorum.org. Current accepted names are shown in bold letters, while new records of lichens in the Philippines are marked with dots [•].

\section{List of manglicolous lichens in Calabarzon, Philippines}

- Anisomeridium ambiguum (Zahlbr.) R.C. Harris (Monoblastiaceae)

Lichen type: crustose

Substrate: bark of Avicenia marina

Distribution: Tanzan Cavite, LLPCHEA, Pagbilao Experimental Mangrove

- Buellia disciformis (Fr.) Mudd (Caliciaceae)

Lichen type: crustose

Substrate: bark of Rhizophora mucronata

Distribution: Navotas Batangas, Pagbilao Experimental Mangrove, Tanza Cavite

Bulbothrix isidiza (Nyl.) Hale (Parmeliaceae)

Lichen type: foliose

Substrate: bark of Rhizophora apiculata

Distribution: Pagbilao Experimental Mangrove, Tanza Cavite

Asia: China, India, Indonesia, Japan, Malaysia, Papua New Guinea, Philippines

Coccocarpia erythroxyli (Spreng.) Swinscow \& Krog (Coccocarpiaceae)

Lichen type: foliose

Substrate: bark of Rhizophora apiculata

Distribution: Pagbilao Experimental Mangrove, Tanza Cavite 
- Collema glebulentum (Nyl. ex Cromb.) Degel. (Collemataceae)

Lichen type: foliose

Substrate: bark of Rhizophora apiculata

Distribution: Pagbilao Experimental Mangrove, Tanzan Cavite

- Cryptothecia striata G. Thor (Arthoniaceae)

Lichen type: crustose

Substrate: bark of Rhizophora apiculata

Distribution: Tanza Cavite, Pagbilao Experimental Mangrove,Batangas

- Diploicia canescens subsp. canescens (Dicks.) A. Massal. (Caliciaceae)

Lichen type: crustose

Substrate: bark of Rhizophra apiculata

Distribution: Tanza Cavite, Pagbilao Experimental Mangrove, Batangas

Dirinaria applanata (Fée) D.D. Awasthi (Caliciaceae)

Lichen type: foliose

Substrate: bark of Rhizophora apiculata

Distribution: Tanza Cavite, Pagbilao Experimental Mangrove, Batangas

- Dirinaria paradoxa (Fée) (Caliciaceae)

Lichen type: foliose

Substrate: bark of Rhizophora apiculata

Distribution: Pagbilao Experimental Mangrove, Tanzan Cavite, Batangas

Dirinaria picta (Sw.) Clem \& Shear (Caliciaceae)

Lichen type: foliose

Substrate: bark of Rhizophora apiculata

Distribution: Pagbilao Experimental Mangrove, Tanzan Cavite, Batangas

- Fissurina cypressi (Müll. Arg.) Lendemer (Graphidaceae)

Lichen Type: crustose

Substrate: Bark on Rhizophora mucronata

Mangrove

Distribution: Tanza Cavite, LLPCHEA, Navotas, Batangas, Pagbilao Experimental

- Graphis caribica Lücking (Graphidaceae)

Lichen type: crustose

Substrate: bark on Avicenia marina, bark of Rhizophora apiculata, bark of Rhizophora mucronata

Distribution: Tanza Cavite, LLPCHEA, Navotas, Batangas, Pagbilao Experimental Mangrove

- Graphis disserpens Nyl. (Graphidaceae)

Lichen type: crustose

Substrate: bark on Rhizophora apiculata, bark of Rhizophora mucronata

Distribution: Tanza Cavite, LLPCHEA, Navotas, Batangas, Pagbilao Experimental Mangrove

- Graphis elegans (Borrer ex Sm.) Ach. (Graphidaceae)

Lichen type: crustose

Substrate: Bark on Rhizophora apiculata 

Mangrove

Distribution: Tanza Cavite, LLPCHEA, Navotas, Batangas, Pagbilao Experimental

Graphis glaucescens Fée (Graphidaceae)

Lichen type: crustose

Substrate: bark and twigs of Avicenia marina

Distribution: Tanza Cavite, LLPCHEA, Navotas, Batangas, Pagbilao Experimental Mangrove

- Graphis intricata Eschw. (Graphidaceae)

Lichen type: crustose

Substrate: bark on Rhizophora mucronata

Mangrove

Distribution: Tanza Cavite, LLPCHEA, Navotas, Batangas, Pagbilao Experimental

Graphis leptoclada Müll. Arg. (Graphidaceae)

Lichen type: crustose

Substrate: bark of Avicenia marina; bark of Rhizophora mucronata

Distribution:

- Graphis phaeospora Vain. (Graphidaceae)

Lichen type: crustose

Substrate: bark of Rhizophora mucronata

Mangrove

Distribution: Tanza Cavite, LLPCHEA, Navotas, Batangas, Pagbilao Experimental

Graphis scripta (L.) Ach. (Graphidaceae)

Lichen type: crustose

Substrate: Bark of Avicenia marina

Mangrove

Distribution: Tanza Cavite, LLPCHEA, Navotas, Batangas, Pagbilao Experimental

- Graphis schiffneri Zahlbr. (Graphidaceae)

Lichen type: crustose

Substrate: bark of Aviceni marina and Rhizophora mucronata

Distribution: Tanza Cavite, LLPCHEA, Navotas, Batangas, Pagbilao Experimental Mangrove

- Graphis subimmersa (Fée) A. Massal. (Graphidaceae)

Lichen type: crustose

Substrate: bark on Rhizophora apiculata, bark of Rhizophora mucronata Mangrove

Distribution: Tanza Cavite, LLPCHEA, Navotas, Batangas, Pagbilao Experimental

- Herpothallon darwiniana Stirt. (Bungartz \& Elix sp.nov.) (Arthoniaceae)

Lichen type: crustose

Substrate: bark on Rhizophora apiculata

Distribution: Tanza Cavite, LLPCHEA, Navotas, Batangas, Pagbilao Experimental Mangrove

- Heterodermia hybocarponica Elix (Arthoniaceae)

Lichen type: foliose 
Substrate: bark of Rhizophora mucronata

Distribution: Pagbilao Experimental Mangrove

- Lecanora albella (Pers.) Ach. (Lecideaceae)

Lichen type: crustose

Substrate: bark of Rhizophora mucronata

Distribution: Tanza Cavite, LLPCHEA, Navotas, Batangas, Pagbilao Experimental Mangrove

- Leptogium cyanescens (Rabenh.) Körb. (Collemataceae)

Substrate: foliose

Substrate: bark of Rhizophora apiculata

Distribution: Pagbilao Experimental Mangrove

- Leptogium denticulatum Tuck. (Collemataceae)

Lichen type: foliose

Substrate: Bark on Rhizophora apiculata

Distribution: Tanza Cavite, Pagbilao Experimental Mangrove

- Opegrapha varians (Müll. Arg.) Vain. (Opegraphaceae)

Lichen type: crustose

Substrate: bark of Rhizophora mucronata

Mangrove

Distribution: Tanza Cavite, LLPCHEA, Navotas, Batangas, Pagbilao Experimental

- Parmelia argena (Ach.) Spreng. (Parmeliaceae)

Lichen type: foliose

Substrate: bark of Rhizophora mucronata

Distribution: Pagbilao Experimental Mangrove

- Parmelia squarrosa Hale (Parmeliaceae)

Lichen type: foliose

Substrate: bark of Rhizophora apiculata

Distribution: Pagbilao Experimental Mangrove

Parmotrema perlatum (Huds.) M. Choisy (Parmeliaceae)

Lichen type: foliose

Substrate: bark of Rhizophora apiculata

Distribution: Pagbilao Experimental Mangrove, Tanza Cavite

Asia: Japan

- Parmotrema pseudonilgherrense (Asahina) Hale (Parmeliaceae)

Lichen type: foliose

Substrate: bark on Rhizophora apiculata

Distribution: Pagbilao Experimental Mangrove, Tanza Cavite

- Pertusaria lactescens Mudd. (Pertusariaceae)

Lichen type: crustose

Substrate: bark of Rhizophora apiculata

Distribution: Tanza Cavite, LLPCHEA, Navotas, Batangas, Pagbilao Experimental Mangrove 
- Phaeographis dendroides (Ach.) Müll. Arg. (Graphidaceae)

Lichen type: crustose

Substrate: bark of Rhizophora apiculata

Distribution: Tanza Cavite, LLPCHEA, Pagbilao Experimental Mangrove

Phlyctis argena (Ach.) Flot (Phlyctidaceae)

Lichen type: crustose

Substrate: bark of Rhizophora mucronata

Distribution: Tanza Cavite, LLPCHEA, Pagbilao Experimental Mangrove

- Physcia aipolia (Ehrh. ex Humb.) Fürnr. (Physciaceae)

Lichen type: foliose

Substrate: bark of Rhizophora mucronata; bark of Rhizophora apiculata

Distribution: Pagbilao Experimental Mangrove, Tanza Cavite

Physcia integrata Nyl. (Physciaceae)

Lichen type: foliose

Substrate: bark of Rhizophora apiculata

Distribution:Batangas, Pagbilao Experimental mangrove, Tanza Cavite

- Polyblastia albida Arnold (Verrucariaceae)

Lichen type: crustose

Substrate: bark of Rhizophora mucronata

Mangrove

Distribution: Tanza Cavite, LLPCHEA, Navotas, Batangas, Pagbilao Experimental

Pyxine cocoes (Sw.) Nyl. (Caliciaceae)

Lichen type: foliose

Substrate: bark of Rhizophora apiculata Mangrove

Distribution: Tanza Cavite, LLPCHEA, Navotas, Batangas, Pagbilao Experimental

- Schismatomma decolorans (Erichsen) Clauzade \& Vězda (Roccellaceae)

Lichen type: crustose

Substrate: bark of Rhizophora mucronata Mangrove

Distribution: Tanza Cavite, LLPCHEA, Navotas, Batangas, Pagbilao Experimental

- Thelidium decipiens (Hepp) Kremp. (Verrucariaceae)

Lichen type: crustose

Substrate: bark of Avicenia marina

Distribution: Tanza Cavite, LLPCHEA, Navotas, Pagbilao Experimental Mangrove

There were 40 manglicolous lichen specimens identified belonging to the three mangrove species. These lichens were further classified belonging to 25 genera and 14 families. The result showed that Rhizophora apiculata (bakawang lalaki) is the most preferred lichen establishment as it houses 23 lichen species. Rhizophora mucronata (bakawang babae) accommodates 17 lichen species while Avicenia marina holds seven lichen species (Fig. 2). Most of these lichens were classified as crustose (60\%) and foliose (40\%) lichens. From these manglicolous lichens, it was also noted that 29 lichen species were new records of lichens in the Philippines.

Aside from the total number of lichen species found in each of the mangrove trees, Rhizophora apiculata (bakawang lalaki) also accommodated 18 host-specific lichen species. 
Rhizophora mucronata (bakawang babae) carries 10 host-specific lichen species and Avicenia marina with 4 (Fig. 2). Lichen belonging to family Arthoniaceae, Caliciaceae, Parmeliaceae, Collemataceae, and Graphidaceae were the highest recorded frequency.

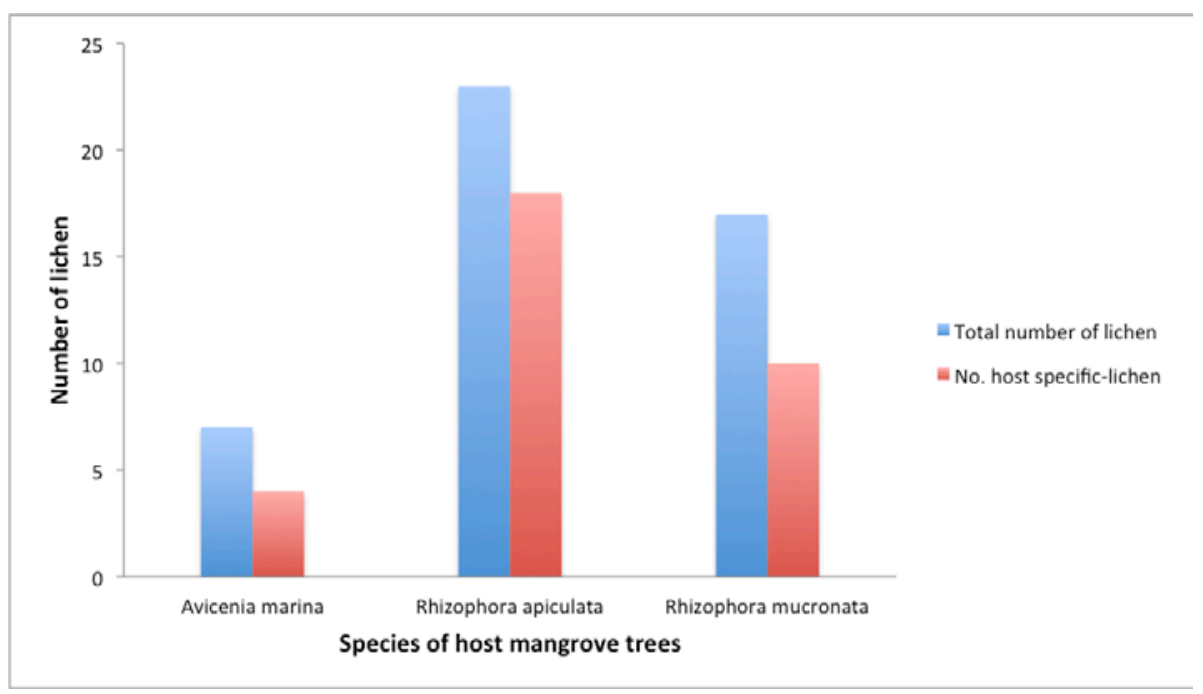

Fig. 2 - Frequency of lichen species housed by mangrove trees in Calabarzon, Philippines

\section{Discussion}

The manglicolous lichens are specific group of lichens in mangrove plants (Panda et al. 2017). These lichens usually thrive in the exposed wood, branches and the bark of mangrove plants, which are considered their ecological niche (Hyde \& Jones 1988). However, mangrove forest has low, dense, and has a high level of salinity affecting the lichen population, which is the reason why crustose lichens are abundant in such habitat (Reynold et al. 2017). The most common manglicolous lichen families includes Arthoniaceae, Caliciaceae, Pyrenulaceae, Parmeliaceae, Collemataceae, and Graphidaceae as recorded by Panda et al. (2017) and Sethy (2015). It was also found that the crustose lichens grow on Avicenia marina with smooth surface and lenticels on their trunk, which supports the result of the study done by Panda et al. (2017) and Nayaka et al. (2012). In the present study, $R$. apiculata and $R$. mucronata has greater lichen diversity compare to $A$. marina because of its thin, stiff and brittle flakes detached to its bark. The foliose lichens were only recorded on $R$. apiculata and $R$. mucronata but no fruticose lichens were observed in any of the three mangrove species, similar to the study by Sethy et al. in 2012.

Mangrove ecosystems differ considerably in physical attributes, composition and age of host tree, substrata available for colonization and salinity. These local environmental factors many have a larger role in deciding the dominant lichen present on each host (Alias et al. 2010). Moreover, absence of fruticose lichens can be linked as these sites with more human interference and unsuitable environment of lichen establishment (Stevens 1979). The agents of lichen destruction includes disturbance of the ecosystems, deforestation, agricultural practices, urbanization, pollution of air, water, soil and exploitation of natural resources (Nash 2008). Field information and the results showed that these sites were less influenced by anthropological activities. The healthy and old mangrove plants favored the luxuriant growth of lichens (Tiwari \& Prajapati 2015).

A total of 40 manglicolous lichen species were recorded from Calabarzon, Philippines (Fig. 2). The present count in Calabarzon is still few compared to other older mangrove ecosystem in the world. However, the occurrence of manglicolous lichens in all regions was almost the same since these lichens interestingly are salt tolerant and more sensitive to moisture (Logesh et al. 2013). This includes the presence of pyrenocarpous lichens that thrives in the moist and humid climate condition of the habitat. The area harbors maximum diversity of lichens under family Graphidaceae, which is similar to the study by Logesh et al. (2012). The second dominant family present in the mangrove ecosystem of Calabarzon is Caliciaceae and Collemataceae, which is 
represented by six and five species respectively. A species under family Roccellaceae was also noted which is considered a unique lichen flora not present anywhere out of the mangroves. These lichen species were also interestingly recorded from the Gujarat mangroves in India (Nayaka et al. 2012). The occurrence of these lichen communities in mangroves indicates their tolerance to hot, humid and saline environmental conditions in mangrove communities (Nayaka et al. 2012).

Of the 40 manglicolous lichens found in the mangrove ecosystem in Calabarzon, Philippines, 29 species of lichens are considered new records of lichens in the Philippines, indicating that this forest type is an important habitat type for lichen diversity (Reynolds et al. 2017). This means that more species are therefore likely to be discovered and added to the Philippine lichen checklist as more sites are investigated.

Just like most mangrove forests, Philippines mangrove forests are usually made of various mangrove tree species. However, the manglicolous lichens noted in Calabarzon when compared with studies elsewhere in the world is relatively low. Marcelli (1992), in his study of the Southern and Southeastern coastline of Brazil recorded the highest number of manglicolous lichen species classified under 289 taxa. One hundred and sixty-seven species thrives in the Sundarban mangroves (Logesh et al. 2013), around 117 species of lichens in the mangroves of Trat Province in Southeast Thailand (Mongkolsuk et al. 2006) and 105 lichen species in the mangroves of eastern Australia (Stevens 1979).

\section{Acknowledgements}

The researchers would like to thank the College of Science, University of Santo Tomas the Fungal Biodiversity Ecogenomics and Systematics (FBeS) Group for their unwavering support in the performance of this study.

\section{Disclosure Statement}

There is NO potential conflict of interest that was reported by the authors.

\section{References}

Alias SA, Zainuddin N, Jones EBG. 2010 - Biodiversity of Marine Fungi in Malaysia Mangroves. Botanica Marina 53, 545-554.

Berja-Lusterio C, Colson L. 2008 - Population, environment and health issues in the Philippines: a profile of CALABARZON (Region 4-A). Population Reference: Bureau. 6 pp. from http://goo.gl/z9hLff (accessed 18 May 2018)

Broad K. 1989 - Lichens in Southern Wood Lands. Forestry Commission Handbook 4.

Gruezo WS. 1979 - Compendium of Philippine lichens. Kalikasan. Philippine Journal of Biology. 8:267-300.

Goward T, McCune B, Meidinger DV. 1994 - The Lichens of British Columbia - Illustrated Keys Part I. Foliose and Squamulose Species. Special series 08, British Columbia: Ministry of Forest Research Program.

Hogarth PJ. 2015 - The Biology of Mangroves and Seagrasses. Oxford University Press, New York.

Hyde KD, Jones EBG. 1988 - Marine Mangrove Fungi .Marine Ecology 9:15-33

Kathiresan K. 2000 - A review of studies on Pichavaram Mangrove, Southeast India. Hydrobiologia 430,185-205

Kathiresan K, Bingham BL. 2001 - Biology of mangrove and mangrove ecosystems. Adv Mar Biol. 40:81-251.

Kohlmeyer J. 1969 - Ecological notes on Fungi in Mangrove Forests. Transactions of the British Mycological Society 52: 237-250.

Logesh AR, Kalaiselvam M, Upreti DK, Nayaka S, Kathiresan K. 2013 - Mangroves - An abode for unique lichens. Coastal ecosystems of India, special publication. Annamalai University: Parangipettai. 39-44. 
Logesh AR, Thillaimaharani KA, Sharmila K, Kalaiselvan M, Raffi SM. 2012 - Production of Chitosan from Endolichenic Fungi Isolated from the Mangrove Environment and it's Antagonistic Activity. Asian Pacific Journal of Tropical Biomedicine 2(2).

Lugo AE, Snedaker SC. 1974 - The Ecology of Mangroves. Annual Review of Ecology and Systematics, 5:39-64. http://dx.doi.org/10.1146/annurev.es.05.110174.000351 (Accessed January 18, 2019).

Malcolm B, Malcolm N, Knight A. 2011 - New Zealand Foliose Lichens - An Illustrated Key. New Zealand: Micro Optics Press.

Marcelli MP. 1992 - Ecologia Liquenica nos Manguezias do Sul-Sudeste Brasileiro. Bibliotheca Lichenologica. 47:1-288.

Margulis L, Barreno E. 2003 - Looking at lichens. Bioscience. 53: 776-778.

McCarthy PM. 2015 - A new species of Lithothelium (lichenized Ascomycota, Pyrenulaceae) from the Tarkine region, north-western Tasmania. Telopea 18: 167-170.

Mongkolsuk P, Buaruang K, Polyiam W, Vongshewarat K et al. 2006 - Lichen in Mangrove forest at Ban Pak Klong Num Chiew Mueng district, and Black Sand Beach Laem Ngob District, Trat Province. 37th Congress of Science and Technology of Thailand; Bangkok. 2011

Muthukumar S, Tarar JL. 2006 - Lichen Flora of Central India, Dattson, J. Nehero Marg Sadar Nagpur

Nash TH. 2008 - Lichen Biology. Cambridge University Press

Nayaka S, Upreti DK, Ingle KK. 2012 - Mangroves of India: Potential Habitats for Unique Lichen Flora. Marine Biodiversity, 68-74.

Odum WE, Heald EJ. 1972 - Trophic Analyses of an Estuarine Mangrove Community. Bulletin of Marine Sciences 22:671-738.

Panda M, Murthy TVR, Samal RN, Lele N et al. 2017 - A comparative study of manglicolous lichens and their distribution inside Bhitarkanika National Park (Odisha), India Studies in Fungi 2 (1): 1-13 http://www.studiesinfungi.com (accessed May 02, 2018)

Primavera JH, Sadaba RB, Lebata MJHL, Altamirano JP. 2004 - Handbook of Mangroves in the Philippines-Panay. SEA. FDEC Aquaculture Department, Iloilo

Reynolds C, Orhan AH Er, Linton W, Dan JB. 2017 - Distribution and community composition of lichens on mature mangroves (Avicenna marina subsp. Australasica (Walp.) J. Everett) in New Zealand.-PLoS ONE 2017, 12, e0180525.

Rai PK, Chutia BM, Patil SK. 2014 - Monitoring of spatial variations of particulate matter (PM) pollution through bio-magnetic aspects of roadside plant leaves in an Indo-Burma hot spot region. Urban Forestry \& Urban Greening 13:761-770.

Raja L, Upreti DK, Kalaiselvam M, Nayaka S, Kandasamy K. 2012 - Lichen flora of Pichavaram and Muthupet mangroves (Southeast Coast of India). Mycosphere. 3. 884-888. 10.5943/mycosphere/3/6/1.

Samson M, Rollon R. 2011 - Mangrove Revegetation Potentials of Brackish-Water Pond Areas in the Philippines. 10.5772/28222.

Santiago KAA, Sangvichien E, Boonpragob K, dela Cruz TEE. 2013 - Secondary metabolic profiling and antibacterial activities of different species of Usnea collected in Northern Philippines. Mycosphere 4(2): 267-280

Sethy P, Pandit G, Sharma B. 2012 - Lichens on mangrove plants in Andaman Islands, India. Mycosphere /3/4/11, 476-484.

Sethy PP. 2015 - Occurrence of Lichen Flora on Mangrove Plants in Adaman Island. Journal of Basic Sciences 2, 132-134.

Smith TJ, Boto KG, Frusher SD, Giddins RL. 1991 - Keystone Species and Mangrove Forest Dynamics: The influence of burrowing by crabs on soil nutrient status and forest productivity. Estuarine Coastal Shelf Science 33,419-432

Stevens GN. 1979 - Distribution and Related Ecology of Macrolichens on Mangroves on the East Australian Coast.The lichenologist 11, 293-305. 
Tiwari SC, Prajapati A. 2015 - Lichen as Indicator of Forest Health Status in Achanakmar: Amarkantak Viosphere Reserve. International Journal of Research Studies in Biosciences (IJRSB) 3(4), 70-79. 